\title{
MODEL PROBLEM BASED LEARNING (PBL) BERBASIS MEDIA INTERAKTIF UNTUK MENINGKATKAN KETERAMPILAN BERPIKIR KRITIS DAN HASIL BELAJAR PADA SUB TEMA LINGKUNGAN TEMPAT TINGGALKU KELAS 4 SD
}

\author{
Yosafat Ardyanto', Henny Dewi Koeswati², Sri Giarti ${ }^{3}$ \\ 1Pendidikan Guru Sekolah Dasar, Universitas Kristen Satya Wacana yosafatardyanto25@gmail.com, \\ 2Pendidikan Guru Sekolah Dasar, Universitas Kristen Satya Wacana dewi@staff.uksw.edu \\ 3Pendidikan Guru Sekolah Dasar, Universitas Kristen Satya Wacana sgiarty@gmail.com
}

\section{INFO ARTIKEL \\ Riwayat Artikel: \\ Diterima: 23-03-2018 \\ Disetujui: 05-04-2018}

\section{Kata Kunci:}

Problem Based Learning, Keterampilan Berpikir Kritis, Hasil Belajar

\begin{abstract}
ABSTRAK
Abstrak: Jenis penelitian ini adalah penelitian tindakan kelas. Tujuan dari penelitian ini untuk meningkatkan kemampuan berpikir kritis dan hasil belajar siswa dalam pembelajaran tematik dengan menerapkan model Problem Based Learning. Hasil penelitian menunjukkan bahwa penerapan model Problem Based Learning dapat meningkatkan kemampuan berpikir kritis dan hasil belajar siswa. Tingkat kemampuan berpikir kritis pada kategori cukup dengan rata-rata pada siklus I adalah 2,71, meningkat di siklus II menjadi 2,98. Ketercapaian ketuntasan hasil belajar siswa pada pra siklus adalah 19\%, meningkat di siklus I menjadi 50\%, kembali mengalami peningkatan di siklus II menjadi $78 \%$.

Abstrak: This type of research is action class. The purpose of this research was to improve the ability of critical thinking and the learning outcomes of students in thematic learning by applying a model of Problem Based Learning. The results showed that the application of the model of Problem Based Learning can enhance critical thinking ability and the learning outcomes of students. The level of ability of critical thinking on considerable category with an average on my cycle was 2.71, rising in second cycle be 2.98. Achiving complete of learning outcomes students on pre-registration cycle is $19 \%$ increase in first cycle became $50 \%$, and incresead in second cycle to be $78 \%$.
\end{abstract}

\section{A. LATAR BELAKANG}

Permendikbud nomor 67 Tahun 2013 mengatakan bahwa Kurikulum 2013 dirancang dengan karakteristik sebagai berikut: 1) Mengembangkan keseimbangan antara pengembangan sikap, spiritual dan sosial, rasa ingin tahu, kreativitas, kerja sama dengan kemampuan intelektual dan psikomotorik. 2) Sekolah merupakan bagian dari masyarakat yang memberikan pengalaman belajar terencana dimana peserta didik menerapkan apa yang dipelajari di sekolah ke masyarakat dan memanfaaat masyarakat sebagai sumber belajar. 3) Mengembangkan sikap, pengetahuani, dan keterampilan serta menerapkannya dalam berbagai situasi di sekolah dan masyarakat. 4) Memberi waktu yang cukup leluasa untuk mengembangkan berbagai sikap, pengetahuan, dan keterampilan. 5) Kompetensi dinyatakan dalam bentuk kompetensi inti kelas yang dirinci lebih lanjut dalam kompetensi dasar matapelajaran. 6) Kompetensi inti kelas menjadi unsur pengorganisasi (organizing elements) kompetensi dasar, dimana semua kompetensi dasar dan proses pembelajaran dikembangkan untuk mencapai kompetensi yang dinyatakan dalam kompetensi inti. 7) Kompetensi dasar dikembangkan didasarkan pada prinsip akumulatif, saling memperkuat (reinforced) dan memperkaya (enriched) antar mata pelajaran dan jenjang pendidikan (organisasi horizontal dan vertical).

Lebih lajut permendikbud no 67 tahun 2013 mengatakan bahwa salah satu pola perubahan kurikulum 2013 yaitu dari pola pembelajaran ilmu pengetahuan tunggal (monodiscipline) yang berubah menjadi pembelajaran ilmu pengetahuan jamak (multidiscipline) menggunakan pendekatan ilmiah (scientific), tematik terpadu (tematik antar mata pelajaran), dan tematik (dalam suatu mata pelajaran) perlu diterapkan dengan pembelajaran berbasis penyingkapan/penelitian (discovery/inquiry learning) atau berbasis pemecahan masalah atau proyek. Proses pembelajaran mulai dari kelas I hingga kelas VI menggunakan model pembelajaran tematik integratif. Kemendikbud (2014: 15) mengatakan bahwa pembelajaran tematik terpadu (PTP) atau integrated thematic instruction (ITI) merupakan sebagai salah satu model pembelajaran yang efektif (highly effective teachingmodel) karena mampu mewadahi dan menyentuh secara terpadu dimensi emosi, fisik, dan 
akademik peserta didik di dalam kelas atau di lingkungan sekolah.

Menurut Rusman (2010: 254) model pembelajaran tematik adalah model pembelajaran terpadu yang menggunakan pendekatan tematik dengan melibatkan beberapa mata pelajaran untuk memberikan pengalaman bermakna kepada siswa karena dalam pembelajaran tematik siswa akan memahami konsepkonsep yang mereka pelajari melalui pengalaman langsung dan menghubungkannya dengan konsep lain yang telah dipahaminya. Berdasarkan uraian diatas dapat disimpulkan bahwa pembelajaran tematik integratif atau tematik terpadu adalah penggabungan dari beberapa pelajaran dengan menggunakan pendekatan tematik untuk memberikan pengalaman bermakna kepada siswa sehingga dapat meningkatkan kapasitas memori peserta didik (enhance learning and increase long-term memory capabilities of learners) untuk waktu yang panjang.

Permendikbud, (2017: 5) menyatakan bahwa pembelajaran kurikulum 2013 merupakan tanggapan dari pembelajaran abad 21, dimana dalam pembelajaran abad 21 terdapat keterampilan yaitu $4 \mathrm{C}$ (Communication, Collaboration, Critical Thinking and Problem Solving, dan Creativity and Innovation ) $4 \mathrm{C}$ adalah jenis softskill yang pada implementasi keseharian, jauh lebih bermanfaat ketimbang sekadar pengusaan hardskill. Dalam penerapannya kurikulum 2013 juga perlu memasukan gerakan literasi sekolah hal ini seperti tercantum dalam Permendikbud No 23 Tahun 2015 yang menyatakan bahwa gerakan literasi merupakan kegiatan 15 menit membaca buku nonpelajaran sebelum waktu belajar dimulai”. Kegiatan ini dilaksanankan untuk menumbuhkan minat baca peserta didik serta meningkatkan keterampilan membaca agar pengetahuan dapat dikuasai secara lebih baik.

Selain itu kurikulum 2013 juga menekankan siswa untuk dapat berpikir tingkat tinggi (HOTS). Gunawan (2003: 171) Higher Order Thinking Skill (HOTS) atau kemampuan berpikir tingkat tinggi adalah proses berpikir yang mengharuskan siswa untuk memanipulasi informasi yang ada dan ide-ide dengan cara tertentu yang memberikan mereka pengertian dan implikasi baru. Pohl dalam Lewy (2009: 15) seperti dikutip dalam jurnal Nur Rochmah lailly mengungkapkan Taksonomi Bloom merupakan dasar bagi berpikir tingkat tinggi. Dasar dari pemikiran ini ialah bahwa beberapa jenis pembelajaran memerlukan proses kognisi yang lebih daripada yang lain, tetapi memiliki manfaat-manfaat yang lebih umum. Krathwohl dalam Lewy (2009: 16) mengatakan bahwa Indikator untuk mengukur kemampuan berpikir tingkat tinggi meliputi menganalisis, mengevaluasi, mencipta. Di dalam pembelajaran guru harus menciptakan suasana yang dapat menumbuhkan minat siswa pada pembelajaran berbasis literasi. Selain itu guru harus dapat membuat pembelajaran yang diajarkan oleh guru mampu mendorong siswa berpikir tingkat tinggi (HOTS) dan pembelajaran tersebut dapat melatih siswa sehingga setiap individu memiliki keterampilan 4C. Jadi berdasarkan uraian di atas guru harus menggalakkan gerakan literasi sekolah, mengajak siswa untuk dapat berpikir tingkat tinggi dan memiliki keterampilan $4 \mathrm{C}$.

Permendikbud No. 67 tahun 2013 menyatakan bahwa pembelajaran kurikulum 2013 menggunakan pembelajaran berbasis penyingkapan/Penelitian (discovery/inquiry learning) atau berbasis pemecagan masalah/proyek ( problem based learning/project based learning). Model pembelajaran berbasis penemuan (Problem Based Learning) adalah proses pembelajaran yang terjadi bila pelajar tidak disajikan dengan pelajaran dalam bentuk finalnya, tetapi diharapkan mengorganisasi sendiri. Model pembelajaran berbasis masalah (problem based learning ) merupakan pembelajaran yang menyajikan masalah kontekstual sehingga merangsang peserta didik untuk belajar. Pembelajaran berbasis proyek (project based learning) merupakan model pembelajaran yang menggunakan proyek/ kegiatan sebagai media. Dari uraian tersebut di atas model yang cocok dengan pembelajaran berbasis keterampilan berpikir kritis adalah model Problem Based Learning karena di dalam model Problem Based Learning siswa dituntut untuk fokus pada masalah, menganalisis argumen, menilai kredibilitas sumber, membuat kesimpulan secara deduktif dan induktif, menilai definisi, mendefinisikan asumsi, dan mengambil keputusan dalam tindakan yang menunjukkan tingginya tingkat berfikir kritis siswa. Menurut Ibrahim dan Nur dalam Cahyo (2013: 285), berpendapat bahwa model Problem Based Learning memiliki beberapa kelebihan diantaranya adalah siswa lebih memahami konsep yang diajarkan, sebab mereka sendiri yang menemukan konsep tersebut, Melibatkan secara aktif memecahkan masalah dan menuntut keterampilan berpikir siswa yang lebih tinggi, pengetahuan tertanam berdasarkan skemata yang dimiliki siswa sehingga pembelajaran bermakna. Hal ini didukung oleh penelitian yang dilakukan I Wayan Redhana (2013: 84) dengan judul penelitian "Model Pembelajaran Berbasis Masalah untuk Peningkatan Keterampilan Pemecahan Masalah dan Berpikir Kritis" yang menyatakan bahwa model pembelajaran berbasis masalah terbukti dapat meningkatkan keterampilan pemecahan masalah dan kemampuan berpikir kritis mahasiswa. Sejalan dengan penelitian I Wayan Redhana, Setyorini, Sukiswo, dan Subali (2011: 55) juga menyatakan dalam penelitiannya yang berjudul "Penerapan Model Problem Based Learning untuk Meningkatkan Kemampuan Berpikir Kritis Siswa" bahwa dengan model pembelajaran Problem Based Learning ( $P B L$ ) dapat meningkatkan kemampuan berpikir kritis siswa dalam mengkomunikasikan dan memecahkan masalah. Dari beberapa penelitian yang sudah dilakukan diatas dapat disimpulkan bahwa model pembelajaran Problem Based 
Learning $(P B L)$ dapat meningkatkan keterampilan berpikir kritis siswa.

Pada kenyataannya Dinas Pendidikan telah melaksanakan kegiatan untuk guru yang berbentuk pelatihan in, on, in (in=pelatihan, on=praktik, in=presentasi dari on) berdasarkan Kurikulum 2013 yang berbasis literasi, HOTS, dan keterampilan $4 \mathrm{C}$. Namun upaya tersebut tidak serta merta mengubah cara mengajar guru . Hal ini sesuai dengan hasil observasi di SD Negeri Dukuh 03 pada kelas 4 yang menunjukkan bahwa guru sudah melakukan gerakan literasi sekolah pada awal pembelajaran, namun guru kurang membimbing siswa sehingga kegiatan itu tidak lagi dilaksanakan. Dalam pembelajaran guru sudah komunikatif dengan siswa selain itu guru juga sudah berkolaboratif dengan siswa. Namun guru belum mengajak siswa untuk berpikir kritis, meskipun ada beberapa siswa yang sudah aktif bertanya dalam pembelajaran tersebut. Rendahnya tingkat keterampilan berpikir kritis siswa ditunjukkan dengan terdapatnya 8 (25\%) anak yang mendapat kriteria C (cukup) atau sudah terlihat memiliki sedikit kemampuan berpikir kritis. Hal ini dilihat dari siswa sudah dapat menentukan masalah utama saat menerima permasalahan yang disampaikan guru untuk dipecahkan.selain itu siswa juga sudah dapat memberikan pendapat yang mendukung atau pendapat yang tidak mendukung terhadap argumen/permasalahan yang disajikan guru. Tetapi disisi lain terdapat 24 (75\%) anak yang mendapat kriteria K (kurang) dengan kata lain sama sekali belum terlihat dapat berpikir kritis. Hal ini terlihat saat siswa diberikan suatu permasalahan oleh guru, siswa masih belum dapat menentukan masalah utama dan belum dapat memberikan pendapat sama sekali. Dari tabel diatas dapat disimpulkan bahwa masih rendahnya kemampuan berpikir kritis siswa kelas IV SD Negeri Dukuh o3.

Rendahnya keterampilan berpikir kritis juga berdampak pada hasil belajar yang rendah. Hal ini dapat dilihat dari hasil belajar siswa yang menunjukkan bahwa dari 32 siswa hanya 6 siswa (19\%) masuk dalam kategori cukup dan mendapatkan nilai di atas KKM yang telah ditetapkan yaitu 70. Sedangkan 26 siswa (81\%) masuk dalam kategori kurang.

Dari hasil studi pendahuluan tentang keterampilan berpikir kritis dan hasil belajar siswa, dapat disimpulkan bahwa masih terjadi kesenjangan yang cukup tinggi. Permasalahan tersebut menyangkut rendahnya presentase pencapaian KKM yaitu hanya $19 \%$. Kesenjangan tingkat keterampilan berpikir kritis siswa juga $75 \%$. Melihat kondisi seperti ini, maka dilakukan perbaikan dengan menerapkan model pembelajaran.

Berdasarkan studi lapangan dan hasil penelitian yang terdahulu maka model pembelajaran $P B L$ dianggap ampuh untuk memperbaiki permasalahan yang terjadi yaitu keterampilan berpikir kritis dan hasil belajar siswa. Oleh karena itu akan dilakukan penelitian tindakan kelas dengan judul "Model Problem Based Learning (PBL) Berbasis Media Interaktif Untuk Meningkatkan Berpikir Kritis Pada Sub Tema Lingkungan Tempat Tinggalku Kelas 4 SD Negeri Dukuh o3 Tahun Pelajaran 2017/2018".

\section{B. METODE PENELITIAN}

Penelitian yang akan dilaksanakan adalah Penelitian Tindakan Kelas (Classroom Action Research). Adapun tujuan penelitian adalah untuk meningkatkan keterampilan berfikir kritis subtema Lingkungan Tempat Tinggalku pada peserta didik kelas IV SD Negeri Dukuh o3 melalui tindakan penerapan model Problem Based Learing berbantuan media interaktif dalam pembelajaran.

Penelitian tindakan kelas termasuk penelitian yang reflektif. Kegiatan penelitian dimulai dari permasalahan yang riil yang dihadapi oleh guru dalam proses belajar mengajar, kemudian direfleksikan alternatif pemecahan masalah tersebut. Setelah itu masalah tersebut ditindaklanjuti dengan tindakan-tindakan terencana dan terukur. Oleh karena itu, penelitian tindakan kelas membutuhkan kerjasama antara peneliti, guru, siswa, dan staf sekolah lainnya untuk menciptakan suatu kinerja sekolah yang lebih baik.

Dalam Penelitian ini penulis menggunakan model PTK yang dikemukakan oleh Kemmis dan Mc.Taggart (1990), dimana terdapat suatu perangkat terdiri dari empat komponen yaitu perencanaan, tindakan, pengamatan, dan refleksi. Keseluruhan unraian tersebut diartikan sebagai satu siklus. Dalam Penelitian Tindakan Kelas (PTK), terdapat beberapa siklus. Banyaknya siklus yang dilaksanakan dalam penelitian tindakan kelas ini tidak ditentukan. Siklus akan selesai jika tujuannya sudah tercapai sesuai dengan rencana yang telah dibuat. Dalam perencanaan penelitian yang akan dilakukan terdapat 2 siklus. Dalam siklus I, terdapat perencanaan I tindakan dan observasi I, refleksi I. Selanjutnya, pada siklus II terdapat beberapa proses, yaitu revisi rencana I dan perencanaan II, tindakan dan observasi II, Kemudian refleksi II. Lebih jelasnya dapat dilihat pada gambar berikut :

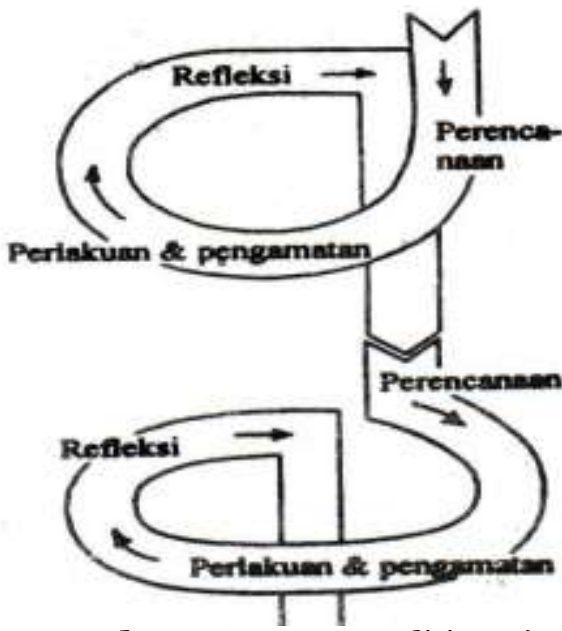

Gambar 1. Proses Penelitian Tindakan Kelas 
(Arikunto, 2002: 84)

Berdasarkan siklus di atas, maka dalam satu kelas akan diberikan beberapa kali tindakan. Banyaknya siklus yang dilaksanakan dalam penelitian tindakan kelas ini tidak ditentukan.

Data dalam penelitian ini diperoleh melalui hasil observasi dan hasil belajar siswa. Dalam penelitian ini data yang diperlukan antara lain: 1) data hasil dari aktifitas guru dalam menerapkan model Problem Based Learning yang diperoleh dari lembar observasi dalam pelaksanaan model pembelajaran Problem Based Learning; 2) data hasil dari aktifitas siswa dalam menerapkan model Problem Based Learning yang diperoleh dari lembar observasi penggunaan model pembelajaran Problem Based Learning; 3) data hasil dari kemampuan berpikir kritis siswa yang didapat dari lembar observasi sesuai dengan indikator kemampuan berpikir kritis yang sudah ditentukan; 4) hasil belajar siswa yang diperoleh melalui tes evaluasi yang diberikan di setiap akhir siklus I dan siklus II selama kegiatan pembelajaran berlangsung.

Kriteria keberhasilan dalam penelitian ini yaitu keberhasilan produk. Kriteria keberhasilan produk dalam berpikir kritis dan hasil belajar siswa didasarkan atas peningkatan keberhasilan siswa dalam mencapai taraf keberhasilan minimal yang ditentukan, yaitu antara $70 \%$ dari jumlah siswa yang mengikuti proses belajar mengajar telah mencapai KKM sebesar 70.

\section{HASIL DAN PEMBAHASAN}

Hasil

\section{Aktivitas Guru}

Berdasarkan kegiatan observasi dengan menggunakan lembar observasi terhadap aktifitas guru selama kegiatan pembelajaran berlangsung dengan menerapkan model Problem Based Learning dapat diperoleh data presentase aktifitas guru pada siklus I dari pertemuan 1 sampai pertemuan VI memperoleh rata-rata skor sebanyak $97 \%$ tergolong kategori sangat baik. Peneliti berupaya untuk menerapkan dan melaksanakan proses pembelajaran sesuai dengan rencana dalam pelaksanaan pembelajaran yang sebelumnya sudah disusun, akan tetapi masih ada beberapa hal yang perlu untuk diperbaiki pada siklus I. Hasil dari observasi aktifitas guru dalam siklus II memiliki presentase skor rata-rata $97 \%$ tergolong dalam kategori sangat baik. Dari hasil data yang diperoleh dalam siklus II menunjukkan bahwa hasil dari observasi aktifitas guru mengalami peningkatan dari siklus sebelumnya.

\section{Aktivitas Siswa}

Hasil dari penilaian aktifitas siswa dalam proses pembelajaran dengan menerapkan model Discovery Learning pada siklus I pertemuan 1 samapi pertemuan VI memperoleh rata-rata skor sebesar 93\% tergolong dalam kategori sangat baik. Peneliti berupaya untuk menerapkan dan melaksanakan proses pembelajaran sesuai dengan rencana pelaksanaan pembelajaran yang sebelumnya telah disusun, tetapi masih ada beberapa hal yang perlu untuk diperbaiki. Hasil dari observasi aktifitas siswa dalam siklus II pertemuan 1 sampai VI mendapat rata-rata skor sebesar $94 \%$ tergolong dalam kategori sangat baik. Dari hasil data yang diperoleh dalam siklus II menunjukkan bahwa hasil dari observasi aktifitas siswa mengalami peningkatan dari siklus sebelumnya.

\section{Analisis Peningkatan Keterampilan Berpikir Kritis dan Hasil Belajar Siswa}

Perbandingan hasil penilaian keterampilan berpikir kritis siswa dari pelaksanaan pra siklus, siklus I, siklus II dapat dilihat dari tabel dan diagaram di bawah ini:

\section{TABEL 1}

PERBANDINGAN KETERAMPILAN BERPIKIR KRITIS SISWA PRA SIKLUS, SIKLUS I, DAN SIKLUS II KELAS 4 SD NEGERI DUKUH 03

\begin{tabular}{|c|c|c|c|c|c|c|c|}
\hline \multirow[t]{2}{*}{ No } & \multirow[t]{2}{*}{ Kategori } & \multicolumn{2}{|c|}{$\begin{array}{l}\text { Pra } \\
\text { siklus }\end{array}$} & \multicolumn{2}{|c|}{ Siklus I } & \multicolumn{2}{|c|}{$\begin{array}{l}\text { Siklus } \\
\text { II }\end{array}$} \\
\hline & & $\mathbf{f}$ & $\%$ & $\mathbf{f}$ & $\%$ & $\mathbf{f}$ & $\%$ \\
\hline 1. & Sangat Baik & - & - & 2 & $6 \%$ & 5 & $\begin{array}{l}16 \\
\%\end{array}$ \\
\hline 2. & Baik & - & - & 10 & $\begin{array}{l}31 \\
\%\end{array}$ & 15 & $\begin{array}{l}46 \\
\%\end{array}$ \\
\hline 3. & Cukup & 8 & $\begin{array}{l}25 \\
\%\end{array}$ & 15 & $\begin{array}{l}47 \\
\%\end{array}$ & 7 & $\begin{array}{l}22 \\
\%\end{array}$ \\
\hline 4. & Kurang & 24 & $\begin{array}{l}75 \\
\%\end{array}$ & 5 & $\begin{array}{l}16 \\
\%\end{array}$ & 5 & $\begin{array}{l}16 \\
\%\end{array}$ \\
\hline & $\begin{array}{l}\text { Nilai } \\
\text { Tertinggi }\end{array}$ & $\begin{array}{l}2,7 \\
5\end{array}$ & & $\begin{array}{l}3,7 \\
5\end{array}$ & & $\begin{array}{l}3,8 \\
8\end{array}$ & \\
\hline & $\begin{array}{l}\text { Nilai } \\
\text { Terendah }\end{array}$ & $\begin{array}{l}1,3 \\
8\end{array}$ & & $\begin{array}{l}1,5 \\
0\end{array}$ & & $\begin{array}{l}1,8 \\
8\end{array}$ & \\
\hline & Rata-rata & $\begin{array}{l}1,9 \\
0\end{array}$ & & $\begin{array}{l}2,7 \\
1\end{array}$ & & $\begin{array}{l}2,9 \\
8\end{array}$ & \\
\hline
\end{tabular}

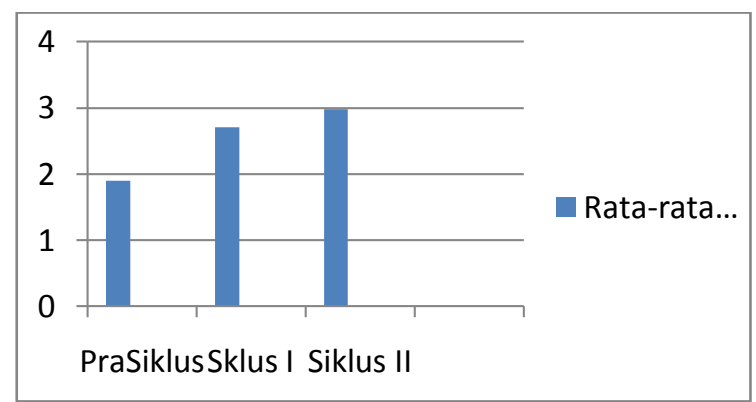

\section{Grafik 2 Perbandingan Keterampilan Berpikir Kritis Siswa Pra Siklus, Siklus I, dan Siklus II Kelas 4 SD Negeri Dukuh o3}

Berdasarkan data yang disajikan pada tabel 1 dan grafik 2 di atas dapat dilihat bahwa hasil penilaian Keterampilan Berpikir Kritis siswa pada pembelajara Sub Tema Lingkungan Daerah Tempat Tinggalku di 
kelas IV SD Negeri Dukuh o3 Salatiga dengan model Problem Based Learning (PBL) berbasis media interaktif dari pra siklus sampai siklus II menunjukkan peningkatan. Hal ini dapat ditunjukkan dengan keterampilan berpikir kritis siswa pada saat pra siklus hanya memperoleh rata-rata kelas sebesar 1,90, setelah memproleh tindakan siklus I rata-rata keterampilan berpikir kritis siswa meningkat menjadi 2,71. Kemudian terjadi peningkatan sebesar 2,98 setelah dilakukan tindakan siklus II. Peningkatan keterampilan berpikir kritis siswa juga berdampak pada hasil belajar siswa. Berikut ini adalah perbandingan peningkatan hasil belajar siswa dari pelaksanaan pra siklus, siklus I, siklus II dapat dilihat dari tabel dan diagaram di bawah ini:

TABEL 2

PERBANDINGAN HASIL BELAJAR SISWA PRA SIKLUS, SIKLUS I, DAN SIKLUS II KELAS 4 SD NEGERI DUKUH 03

\begin{tabular}{|l|c|c|c|c|c|c|}
\hline \multirow{2}{*}{ Ketuntasan } & \multicolumn{2}{|l|}{ Pra siklus } & \multicolumn{2}{l|}{ Siklus I } & \multicolumn{2}{l|}{ Siklus II } \\
\cline { 2 - 7 } & F & \% & f & \% & f & \% \\
\hline Tuntas & 6 & $19 \%$ & 16 & $50 \%$ & 25 & $78 \%$ \\
\hline $\begin{array}{l}\text { Tidak } \\
\text { Tuntas }\end{array}$ & 26 & $81 \%$ & 16 & $50 \%$ & 7 & $22 \%$ \\
\hline Jumlah & 32 & $100 \%$ & 98 & $100 \%$ & 99 & $100 \%$ \\
\hline
\end{tabular}

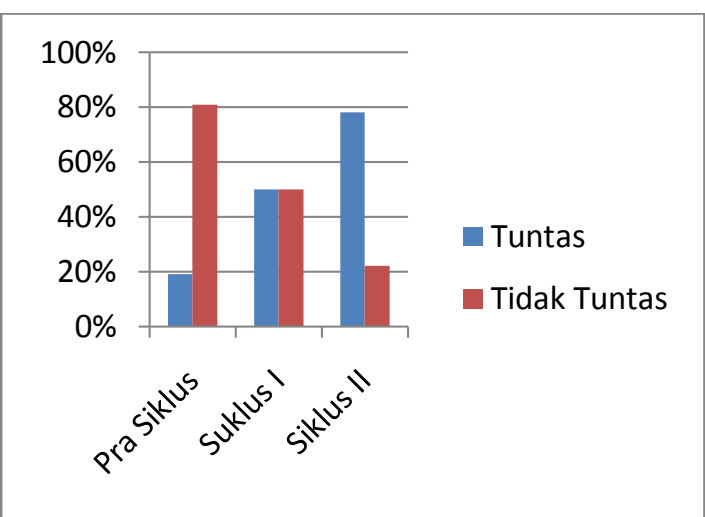

Grafik 3. Perbandingan Keterampilan Berpikir Kritis Siswa Pra Siklus, Siklus I, dan Siklus II Kelas 4 SD Negeri Dukuh 03

Berdasarkan data yang disajikan pada tabel 2 dan grafik 3 di atas dapat dilihat bahwa Hasil Belajar siswa pada pembelajara Sub Tema Lingkungan Daerah Tempat Tinggalku di kelas IV SD Negeri Dukuh o3 Salatiga dengan model Problem Based Learning (PBL) berbasis media interaktif dari pra siklus sampai siklus II menunjukkan peningkatan. Hal ini dapat ditunjukan pada siklus I jumlah siswa yang mencapai ketuntasan (70) meningkat menjadi 16 (50\%) siswa atau mengalami peningkatan sebesar 31\% jika dibandingkan dengan pra siklus. Kemudian karena indikator keberhasilan belum tercapai maka dilakukan tindakan siklus II dengan hasil peningkatan yang cukup baik. Hal ini dapat dilihat pada siklus II jumlah siswa yang mencapai ketuntasan (70) meningkat menjadi 25 (78\%) siswa atau mengalami peningkatan sebesar $59 \%$ jika disbanding dengan pra siklus dan meningkat 28\% jika dibandingkan dengan siklus I.

\section{Pembahasan}

Kondisi awal keterampilan berpikir kritis siswa siswa kelas IV SD Negeri Dukuh o3 Salatiga menunjukkan bahawa nilai rata-rata keterampilan berpikir kritis siswa kelas IV adalah 1,90 dan termasuk pada kategori K (kurang) yang berpengaruh pada hasil belajar siswa, dimana hanya terdapat 6 siswa yang mencapai ketuntasan klasikal atau sebanyak 19\% siswa dari keseluruhan siswa. Berdasarkan pada hal tersebut, maka diterapkan pembelajaran dengan menggunakan model Probelem Based Learning (PBL) berbasis media interaktif untuk meningkatkan keterampilan berpikir kritis siswa dan hasil belajar siswa.

Dalam tidakan penelitian dilaksanakan dengan berkolaborasi dengan guru kelas IV, dimana tindakan tersebut dilaksanakan dalam dua siklus dan untuk setiap siklusnya terdiri dari enam pertemuan. Melalui penerapan model Probelem Based Learning ( $P B L)$ berbasis media interaktif pembelajaran diatur dalam lima tahapan yang dimulai dari 1) Mengorientasi siswa kepada masalah. 2) engorganisasikan siswa. 3) Membimbing penyelidikan individu dan kelompok. 4) mengembangkan dan menyajikan hasil karya. 5) menganalisa dan mengevaluasi proses pemecahan masalah Kemendikbud (2014: 28). Hal ini bertujuan untuk meningkatkan keterampilan berpikir kritis dan hasil belajar siswa.

Dalam pelaksanaan penelitian ini, peneliti menggunakan tes untuk megukur keterampilan berpikir kritis siswa dan hasil belajar siswa, lembar observasi guru dan lembar observasi siswa digunakan untuk mengamati dan mengecek apakah proses pembelajaran sesuai dengan rancangan tindakan yang telah dibuat, dokumentasi foto sebagai bentuk gambaran konkret tentang segala kegiatan yang ada untuk memperkuat. Berdasarkan hasil observasi guru dan siswa pada siklus I dan siklus II, siswa antusias mengikuti pembelajaran. Proses pembelajaran secara berkesinambungan mengalami peningkatan, hal ini terlihat dari kerjasama guru dan siswa dalam membangun proses pembelajaran serta keterlibatan siswa dalam pembelajaran yang cukup maksimal.

Setelah dilakukan tindakan siklus I dan siklus II dengan menerapkan model Problem Based Learning $(P B L)$ berbasis media interaktif menunjukkan peningkatan keterampilan berpikir kritis siswa. Hal ini dapat ditunjukkan dengan perbandingan peningkatan keterampilan berpikir kritis dan hasil belajar siswa. Pada saat pra siklus hanya memperoleh rata-rata kelas sebesar 1,90, setelah memproleh tindakan siklus I ratarata keterampilan berpikir kritis siswa meningkat menjadi 2,71. Kemudian terjadi peningkatan sebesar 2,98 setelah dilakukan tindakan siklus II. Peningkatan keterampilan berpikir kritis siswa juga berdampak pada hasil belajar siswa. Hal ini dapat dilihat dari peningkatan hasil belajar dari pra siklus sampai dengan tindakan siklus I dan siklus II. Hasil belajar yang diperoleh siswa 
pada pra siklus hanya terdapat $6(19 \%)$ siswa yang dapat mencapai KKM (70), sebanyak 26 (81\%) siswa masih memperoleh nilai di bawah KKM (70) dan perolehan rata-rata kelas sebanyak 46,6.

Setelah dilakukan tindakan siklus I hasil belajar yang diperoleh siswa meningkat, terdapat 16 (50\%) siswa dapat mencapai KKM (70), 16 (50\%) masih dibawah KKM (70) dan perolehan rata-rata kelas sebanyak 65. Hal ini menunjukkan bahwa tindakan penelitian siklus I dikatakan belum berhasil karena masih terdapat kekurangan yang terjadi diantaranya dalam mengorientasikan siswa kepada masalah guru belum memberikan permasalahan secara kontekstual, suasana kelas yang belum kondusif membuat pembelajaran yang disampaikan guru menjadi tidak maksimal, dalam membimbing dikusi kelompok guru masih belum aktif dalam melakukan pembibingan sehingga siswa enggan berpartisipasi dalam diskusi kelompok, dan dalam menyajikan hasil karya banyak siswa yang lebih memilih untuk sibuk sendiri. Penelitian dilanjutkan ke siklus II dengan memperbaiki pembelajaran sesuai dengan perbaikan hasil refleksi. Perbaikan tersebut diantaranya guru harus memberikan permasalahan kontekstual kepada siswa, untuk mengondisikan kelas agar lebih kondusif sebelum guru memulai pembelajaran guru dan siswa membuat perjanjian untuk mengikuti pembelajaran dengan baik, dalam membimbing penyelidikan kelompok guru harus lebih sering berkeliling untuk membimbing diskusi kelompok siswa, untuk membuat siswa lebih berpartisipatif dalam menyajikan hasil karya guru harus memberikan apresiasi setelah siswa mempresentasikan hasil pekerjaannya di depan kelas, guru harus menanamkan sikap menghargai pada diri siswa agar selalu memperhatikan jika ada orang yang sedang berbicara.

Pada tindakan siklus II kondisi pembelajaran lebih kondusif, siswa antusias dan berpasitipasi aktif dalam kegiatan diskusi kelompok maupun saat menyajikan hasil karya sehingga hasil belajar pada siklus II meningkat. Hal ini dapat dilihat dari hasil belajar yang diperoleh, terdapat 25 (78\%) siswa dapat mencapai KKM (70), 7 (50\%) masih dibawah KKM (70) dan perolehan rata-rata kelas sebanyak 71,09 . Hal ini menunjukkan bahwa tindakan penelitian siklus II dikatakan sudah berhasil karena telah melampaui indikator keberhasilan yang sudah ditentukan yaitu 70\% dari jumlah siswa yang mendapat nilai mencakapai KKM (70). Hal ini dapat dilihat sebanyak $78 \%$ dari jumlah siswa yang mengikuti proses belajar mengajar telah mencapai KKM (70). Berdasarkan perolehan nilai yang diperoleh siswa pada siklus I dan siklus II dapat disimpulkan bahwa model Problem Based Learning Berbasis (PBL) berbasis media interaktif adalah salah model yang memiliki keunggulan untuk meningkatkan keterampilan berpikir kritis siswa dan hasil belajar siswa pada sub tema Lingkungan
Tempat Tinggalku kelas IV SD Negeri Dukuh o3 Salatiga tahun pelajaran 2017/2018.

Hasil penelitian ini juga sejalan dengan kajian penelitian yang relevan yang dilakukan oleh I Wayan Redhana (2013: 84) dengan judul penelitian "Model Pembelajaran Berbasis Masalah untuk Peningkatan Keterampilan Pemecahan Masalah dan Berpikir Kritis" yang menyatakan bahwa model pembelajaran berbasis masalah terbukti dapat meningkatkan keterampilan pemecahan masalah dan kemampuan berpikir kritis mahasiswa. Sejalan dengan penelitian I Wayan Redhana, Setyorini, Sukiswo, dan Subali (2011: 55) juga menyatakan dalam penelitiannya yang berjudul "Penerapan Model Problem Based Learning untuk Meningkatkan Kemampuan Berpikir Kritis Siswa" bahwa dengan model pembelajaran Problem Based Learning $(P B L)$ dapat meningkatkan kemampuan berpikir kritis siswa dalam mengkomunikasikan dan memecahkan masalah.

Penerapan model Problem Based Learning (PBL) berbasis media interaktif terbukti dapat meningkatkan hasil belajar siswa pada sub tema Lingkungan Tempat Tinggalku kelas IV SD Negeri Dukuh o3 Salatiga tahun pelajaran 2017/2018. Implikasi praktis yang terjadi setelah pelaksanaan penlitian tindakan kelas ini yaitu guru dapat menggunakan model pembelajaran yang praktis, inovatif, kreatif, dan menyenangkan untuk memperbaiki mutu pembelajaran. Guru dapat menerapkan tindakan perbaikan pembelajaran sebagai upaya meningkatkan profesionalisme kerja. Serta pengetahuan dan keterampilan guru juga semakin berkembang dengan menggunakan model-model pembelajaran yang praktis, inovatif, kreatif, dan menyenangkan.

\section{SIMPULAN DAN SARAN}

\section{Simpulan}

Berdasarkan hasil dan pembahsan pada BAB IV, dapat diambil kesimpulan bahwa penelitian tindakan kelas yang dilakukan kolaboratif oleh peneliti dan guru kelas dapat meningkatan keterampilan berpikir kritis dan hasil belajar siswa kelas IV pada sub tema Lingkungan Tempat Tinggalku dengan menggunakan model Problem Based Learning (PB) berbasis media interaktif di SD Negeri Dukuh o3 Salatiga tahun pelajaran 2017/2018, berikut adalah kesimpulan dari hasil analisis: Melalui penerapan model pembelajaran Problem Based Learnig (PBL) berbasi media interaktif dapat meningkatkan keterampilan berpikir kritis dan hasil belajar siswa kelas 4 SD Negeri Dukuh 03 yang ditandai dengan kenaikan nilai keterampilan berpikir kritis yang mengakibatkan hasil belajar juga ikut meningkat.

\section{Saran}

Berdasarkan hasil penelitian yang telah dilakukan, peneliti memiliki bebera saran sebagai berikut.

\section{Bagi siswa}


a. Seharusnya siswa memperhatikan apa yang dilakukan guru.

b. Dalam kegiatan berdiskusi sebaiknya lebih berpartisipasi aktif.

c. Ketika ada siswa yang mempresentasikan hasil pekerjaan di depan, sebaiknya siswa yang lain ikut mendengarkan dan memperhatikan.

\section{Bagi guru}

a. Sebaiknya guru sering berkeliling kelas untuk membimbing siswa dalam kegiatan berkelompok.

b. Guru seharusnya menanamkan rasa saling menghormati sesama siswa ketika salah satu siswa mempresentasikan hasil pekerjaannya di depan maka siswa lain memperhatikan.

c. Permasalahan yang diajukan oleh guru seharusnya mengacu pada fakta yang ada sehingga siswa mudah untuk memahami permasalahan dari guru.

\section{Sekolah}

a. Memfasilitasi guru dalam melaksanakan kegiatan diskusi kelompok.

b. Memberikan ilmu pengetahuan tentang model Problem Based Learning (PBL).

\section{Bagi Peneliti Lain}

Hasil penelitian dapat digunakan sebagai referensi untuk peneliti lain saat melakukan penelitian yang sama dan diharapkan penelitian selanjutnya lebih baik dari penelitian sebelumnya.

\section{UCAPAN TERIMA KASIH}

Penulis mengucapkan terimakasih kepada Ibu Dr Henny Dewi Koeswati, S.Pd., M.Pd selaku Pembimbing 1 dan Ibu Sri Giarti, S.Pd., M.Pd selaku Pembimbing 2 yang senantiasa memberikan bimbingan, nasehat, motivasi dan tempat ngeluh tiap kesulitan ngerjain kepada penulis sehingga penelitian ini selesai dengan baik.

\section{DAFTAR PUSTAKA}

[1] Kemendikbud. 2014. Materi Pelatihan Guru Implrmrntasi Kurikulum 2013 Tahun 2014. Kemendikbud.

[2] Permendikbud Nomor 67 Tahun 2013.

[3] Permendikbud. 2017. Pusat Penelitian Pendidikan Badan Penelitian dan Pengembangan Kementrian Pendidikan dan Kebudayaan. Kemendikbud.

[4] Shobirin, ma'as. 2016. Konsep dan Implementasi Kurikulum 2013 di Sekolah Dasar. Yogyakarta: Deepublish.

[5] Trianto. 2009. Mengembangkan Model Pembelajaran Tematik. Jakarta: Prestasi Pustaka

[6] Majid, Abdul. 2014. Pembelajaran Tematik Terpadu. Bandung: PT Remaja Rosdakarya.

[7] Daryanto. (2011). Penelitian Tindakan Kelas dan Penelitian Tindakan Sekolah . Yogyakarta: Gava Media.

[8] Tampubolon, S. (2014). Penelitian Tindakan Kelas Sebagai Pengembangan Profesi Pendidik dan Keilmuan. Bandung: Penerbit Erlangga.

[9] Rusman. (2013). Model-Model Pembelajaran "Mengembangkan Profesionalisme Guru" Edisi Kedua. Jakarta: Raja Grafindo Persada.
[10] Hopkins, D. (2011). Panduan Guru Penelitian Tindakan Kelas. Yogyakarta: Pustaka Belajar.

[11] Nitko, A.J. \& Brookhart, S.M. (2011). Educational Assessment of Student ( $6^{\text {th }}$ ed). Boston: Pearson Education.

[12] Dedi Miswar, Yarmaidi, Endang Sasmita. (2016). Perbedaan Penerapan Model Problem Based Learning Pada Hasil Belajar Geografi. Yogyakarta: Media Akademi.

[13] Rusman. (2017). Belajar \& Pembelajaran "Berorientasi Standar Proses Pendidikan". Jakarta: Kencana.

[14] Murfiah, U. (2017). Pembelajaran Terpadu "Teori dan Praktik Terbaik Di Sekolah". Bandung: Refika Aditama.

[15] Kosasih,E. 2016. Strategi Belajar dan Pembelajaran. Bandung: Yrama Widya.

[16] Desmita. 2011. Psikologi Perkembangan siswa. Bandung: Remaja Rosdakarya

[17] Nyanyu Khodijah. 2014. Psikologi Pendidikan. Jakarta: Rajawali Pers

[18] Eti Nurhayati. 2011. Psikologi Pendidikan Inovatif. Yogyakarta: Pustaka Pelajar

[19] Dimyati dan Mudjiono. 2009. Belajar dan Pembelajaran. Jakarta: Rineka Cipta

[20] Hamalik, Oemar. 2008. Proses Belajar Mengajar. Jakarta: Sinar Grafika

[21] Suprijono, Agus. 2013. Cooperative Learning. Surabaya: Pustaka Belajar

[22] Jihad, A. dan Abdul Haris. 2012. Evaluasi pembelajaran. Yohyakarta: Multi Presindo

[23] Sudjana. 2009. Metode Stastistika. Bandung: Tarsito

[24] Slameto. 2010. Belajar dan Faktor-Faktor Yang Mempengaruhinya. Jakarta: Rineka Cipta

[25] Daryanto, 2014. Pembelajaran Tematik Terpadu Terintegrasi (Kurikulum 2013). Yogyakarta: Gava Media.

[26] Sadiman, Arief S dkk. 2006. Media Pendidikan Pengertian, Pengembangan, dan Pemanfaatannya. Raja Grafindo. Jakarta

[27] Azhar, Arsyad.2011. Media Pembelajaran. Jakarta: Rajawali Pers

[28] Rayandra, Asyar. 2012. Kreatif Mengembangkan Media Pembelajaran. Jakarta: Gaung Persada Press

[29] Yudhi, Munadi. 2008. Media Pembelajaran; Sebuah Pendekatan Baru. Jakarta: Gaung Persada Press

[30] Rini, Rismaerista dan Mawardi. (2015). Peningkatan Keterampilan Proses Saintifik Dan Hasil Belajar Siswa Kelas 4 SDN Slungkep 02 Tema Peduli Terhadap Makhluk Hidup Menggunakan Model Problem Based Learning. Jurnal Scholaria, Vol. 5, No. 1, Januari 2015:103 -113.

[31] Giarti, Sri. (2014). Peningkatan Keterampilan Proses Pemecahan Masalah Dan Hasil Belajar Matematika Menggunakan Model Pbl Terintegrasi Penilaian Autentik Pada Siswa Kelas VI SDN 2 Bengle, Wonosegoro. Jurnal Scholaria, Vol. 4, No. 3, September 2014: 13-27.

[32] Setyorini U., Sukiswo S.E, dan Subali B. (2011) Penerapan Model Problem Based Learning Untuk Meningkatkan Kemampuan Berpikir Kritis Siswa SMP. Jurnal Pendidikan Fisika Indonesia 7(2011) 52-56.

[33] Redhana, I Wayan. (2013). Model Pembelajaran Berbasis Masalah Untuk Peningkatan Keterampilan Pemecahan Masalah dan Berpikir Kritis. Jurnal Pendidikan dan Pengajaran, Jilid 46, Nomor 1, April 2013, hlm. 76-86. 


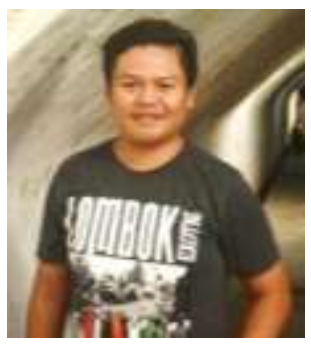

\section{BIODATA PENULIS}

Penulis bernama lengkap "Yosafat Ardyanto". Lahir di Kab. Semarang Tengah pada tanggal 20 Februari 1996 dari pasangan Sutopo dan Winarah Aniswati. Penulis adalah anak ketiga dari 4 bersaudara. Pendidikan sekolah dasar dimulai dari SDN Kalibeji o1 Kecamatan Tuntang pada tahun 2002 - 2008. Setelah itu melanjutkan pendidikan sekolah menengah ke SMPN Banyubiru pada tahun 2008 - 2011 dan terakhir di SMKN 2 Salatiga pada tahun 2011 - 2014. Selanjutnya melanjutkan pendidikan di Pendidikan Guru Sekolah Dasar Universitas Kristen Satya Wacana Salatiga 2014 sampai sekarang. Kritik, saran, maupun hal-hal yang berkaitan dengan kelanjutan atau pengembangan dari hasil penelitian ini bisa dikirim ke email penulis di : yosafaratrdyanto25@gmail.com 